\title{
INTEGRATING ISLAMIC VALUES INTO THE DEUELOPMENT OF ANNOUNCEMENT AND NOTICE UNIT FOR THE EIGHTH GRADE IN MTS MADANI PAO-PAO
}

\author{
Andi Zahra \\ Universitas Islam Negeri Alauddin Makassar \\ andiizahra27@gmail.com \\ Andi Asmawati \\ Universitas Islam Negeri Alauddin Makassar \\ Andi.asmawati@uin-alauddin.ac.id \\ Kamsinah \\ Universitas Islam Negeri Alauddin Makassar \\ Kamsinah@uin-alauddin.ac.id
}

\begin{abstract}
English material that is used in the school is too general. It is also already not reflecting Islam itself. To maintain students' identity as Muslim, this paper is aimed to integrate Islamic Values into English material especially in basic competences 3.12 and 4.12 about Announcement and Notice for the eighthgrade students at MTs Madani Pao-Pao based on 2013 curriculum. The research design used in this study was Research and Development (R\&D). The development model used was ADDIE model. It consists of need analysis, design, development, implementation, and evaluation. The procedures included analyzing materials needed by spreading questionnaire to the students and analyzing the basic competences used, designing a blueprint of materials, and developing the English materials through ADDIE model. In this research, the expert was involved in order to validate the product. There were two systematic aspects the product that they validated: the aspect of the content/material and aspect of learning. Therefore, the result indicated that based on experts' judgment as well as product development result, the developed basic competences 3.12 and 4.12 was applicable to be taught at the eighth-grade students of Junior High School as topics in English.
\end{abstract}

Keywords: Development, Islamic values, English material

\section{INTRODUCTION}

Islam is the most trusted religion by people in the world, also in Indonesia. Islam really appreciates everything that can provide benefit for people, especially education. Islam laid a great deal of stress on educational aspect from beginning, because of its importance in the life of human beings (Darwis, 2008: 179). One of the best ways in acquiring knowledge is by reading. As Allah pronounced in (QS. Al-'Alaq:1-5) that:

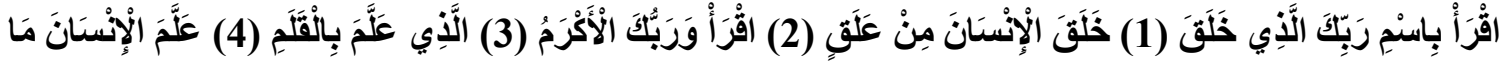

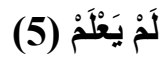




\section{Meaning:}

"(1) Read, in the name of the Lord. (2) Who created, created man from a cloth of congealed blood. (3) Read! And thy Lord is most bountiful. (4) He who taught the use of the pen. (5) Taught man that which he knew not."

This surah guides us as Muslim to gain knowledge as much as we can. It means that Islam regards education as an important thing for our life. Jalaluddin (2016: 1) also stated that education is the most believed effort to be the most effective in realizing the values of Islamic teachings entirely and comprehensively. It can be said that the existence of education is very beneficial because it can be used as a means of conveying that Islam itself.

In education, curriculum plays a significant role. The curriculum is a set of plans and arrangements regarding the objectives, contents, and teaching materials as well as the methods used to guide the implementation of learning activities to achieve national education goals. However, before planning teaching material that will be given to students, it is necessary to do need analysis first. As Yaumi (2016: 57) stated that before going far in the design process, the first step that needs to be considered by the designer or developer is to identify learning needs.

Besides, Curriculum development is also needed in education, it can be done by redesigning syllabi. As Yassi \& Kaharuddin (2018: 14) stated that one of the efforts is to develop the existing curriculum by redesigning syllabi used in the institutions into welldesigned courses syllabi for teaching English. Richards (2001:2) added that curriculum development is a more comprehensive processes that syllabus design. It includes the processes that are used to determine the needs of a group of learners, to develop aims or objectives for a program to address those needs, to determine an appropriate syllabus, course structure, teaching methods, and materials, and to carry out an evaluation of the language program that result from these processes.

The product or result of the curriculum development then will be made in a textbook. We know that all subjects need a textbook or learning material to facilitate learning process. One indicator of the success of the learning process is the availability of learning materials (Yaumi, 2016: 273). As one of the subjects which is taught at school, English Language Teaching also needs textbook in teaching process. However, English material has brought western cultures and impact in education. At this moment, cultural and religious values in education have decreased. According to Amri (2014: 1) education in Islam is currently having a setback crisis, this is due to incomplete material aspects, social and cultural crisis, as well as the loss of good role model, good faith, and Islamic values. 
We cannot deny that western culture an absolute different value with Indonesian culture, especially with Islamic value. Therefore, to make Islamic values still exists in English teaching, we have to integrate the lesson with Islamic values. Annisa and Hadija (2017) stated that language, culture, and local wisdom; religious values are inseparable so that teaching English has to teach both of language and local contents. Integrating Islamic messages in the English teaching may prevent students from feeling bewildered.

Nowadays, a lot of English textbooks have spread all over the formal or non-formal educational institutions around the world and also in Indonesia, especially Madani Islamic Junior High School. Madani Islamic Junior High School is one of schools that has Islamic basic where there are several subjects integrated with Islamic values. This school is a subordinated school of UIN Alauddin Makassar and also as a laboratory of Tarbiyah and Teaching Faculty. As the vision of UIN Alauddin Makassar that the center for enlightening and trans-formatting science and technology based on Islamic civilization, the subjects in this school also have to be integrated with Islamic values.

Moreover, in Curriculum 2013, there are some character buildings needs to do. One of them is religious character. Announcement and Notice is a material which is taught at the eighth grade of Junior High School. This material is one part of the short functional text material. Short Functional Text is a short text that has particular meaning and purpose, and can be used in our daily life. By integrating Islamic values into this material, students will get both English knowledge and Islamic values.

\section{METHOD}

\section{Respondents}

The subject of this research was the students of the eighth grade of MTs Madani Pao-Pao. The total number of the eighth-grade students is 217 and $8 \mathrm{E}$ class was the sample of this research which consists of 35 students, the English teacher of Mts Madani Pao-Pao, and two experts.

\section{Instruments}

In this research, the researcher used three instruments. Document, questionnaire and validation checklist were made by researcher and filled by the experts.

1. Document contained the syllabus of 2013 curriculum and basic competence.

2. Questionnaire was used to find out students' need. The organization of the questionnaire divided into three parts as follows: 
Table 1. The organization of the questionnaire

\begin{tabular}{ccll}
\hline No. & \multicolumn{1}{c}{ Aspects } & & \multicolumn{1}{c}{ Indicator } \\
\hline A & The organization of material & $\bullet$ & Instructional objectives \\
& & $\bullet$ & Activities \\
& & $\bullet$ & Summary \\
& & $\bullet$ & Reflection time \\
& & $\bullet$ & Words list \\
\hline B $\quad$ Content of the material & $\bullet$ & Topics \\
\hline C & Learners' characteristic & $\bullet$ & Learning style \\
\cline { 3 - 4 } & & $\bullet$ & Learning preferences \\
\cline { 2 - 3 } & & $\bullet$ & Learning problems \\
& & \\
\end{tabular}

3. Validation Checklist was used as a tool used by experts in assessing and evaluating products that produced/developed by researcher. The validation checklist adapted from Anggraeni (2012). The organization of the questionnaire divided into four parts as follows:
a) Material aspect
b) Learning aspect
c) Graphics feasibility aspect
d) Notes of errors and recommendations
e) Comments and suggestions

\section{Procedures}

This data collection carried out through the five phases of ADDIE Model which are; the first phase namely analysis, the researcher distributed the questioner that had made by adopting Yassi \& Kaharuddin (2018) find out the students' need about Announcement and Notice so that the material filtered according to students' needs; the second phase namely material design, in this phase the results of the questionnaire collected as a reference in making the materials, then the research began to compile the material that had been selected. The researcher presented the filtered material in the previous phase. The third phase namely developing material, the researcher collected all the material that had been compiled then developed the material into subject matter based on Islamic values and considered the results of the questionnaire answered by students, the fourth phase namely implementation and the last phase is evaluation. However, due to the limitation of time and pandemic situation, both implementation and evaluation phases was skipped, the development material was only given to the experts and the teacher to be validated.

\section{Data Analysis}


In this research, the researcher used qualitative and quantitative data analysis technique to analyze the data. The data obtained from the students analyzed quantitatively to know the average score for the rubric for experts and each question given to the students

Firstly, gathering information from students and experts the researcher by analyzing the students' needs using questionnaires and validation checklist. The researcher then used closedended question in getting students' needs.

All the data then analyzed to recognize the needs inventory of students in English which is used as the basis for formulating the blue print/the design of the materials.

Secondly, data analysis technique used to find the level validity of the product developed displayed below:

$$
\overline{\mathrm{X}}=\frac{y 1+y 2}{\mathrm{n}}
$$

Where:

$\overline{\mathrm{X}}=$ The average of rating scale

$\mathrm{y}=$ The expert

$\mathrm{n}=$ Total number of experts

\section{FINDINGS AND DISCUSSION}

\section{Findings}

\section{The result of Needs Analysis Phase}

\section{a. The result of content materials based on the syllabus}

The result of the need analysis is based on the syllabus of 2013 curriculum covering the basic competences 3.12 and 4.12 about Announcement and Notice were expected to be able to understand by the students. Firstly, the topic designed and divided into two subtopics which were suitable with the amount of meeting learning. In other words, Announcement and Notice materials were developed in two subtopics.

The first meeting shows Announcement material and the second meeting shows notice material. Secondly, every meeting had a core skill that was integrated one another in flows of skill that were arranged systematically. Then, learning activities dealt with scientific approach included observing, questioning, collecting information, associating, and communicating. The last, the development of learning instruction referring to pre-study; the type of activities consisted of individual, pair, and group activity; the number of activities; text structure and glossary. These materials were developed in order to provide suitable materials for the eighthgrade students in MTs Madani Pao-Pao. 


\section{b. The result of need analysis of Expert judgment suggestion}

The questionnaire used by the researcher to analyze the students' needs was designed. It was designed by deciding the components that would be put on the questionnaire that had three parts. The first part related to the organization of materials that was consisted of six questions. The point of the questions was to know the target of the systematic materials. Furthermore, in the second part that consisted of two questions related to the content of materials. These questions were pointed the topics of the material that applicable for the students. Then, in the third part that consisted of four questions related to the learners' characteristic, the point of these questions was to know students' styles, preferences and problems.

Moreover, this questionnaire was not distributed directly to the students. It was given to the expert to correct and to give suggestion according to the questionnaire made. Then, the expert was giving a suggestion to change and delete some components that is not important to be put on the questionnaire. The result of the final questionnaire then distributed to the students. However, the questionnaire given to the students was in Indonesian version to avoid students' misunderstanding. Hence, the result of this questionnaire was accepted and validated by the expert since it was relevant and applicable for the students.

\section{c. The result of need analysis of developing learning materials based on the students' questionnaires}

The results of the analysis of the need for learning material development based on the student questionnaires. The questionnaires consist of three parts. The first is the organization of material, the second is content of the material, the third is learner's characteristic. After distributing the questionnaires, then the findings were concluded in this part into a table as shown below:

Table 2. Result of questionnaire part A

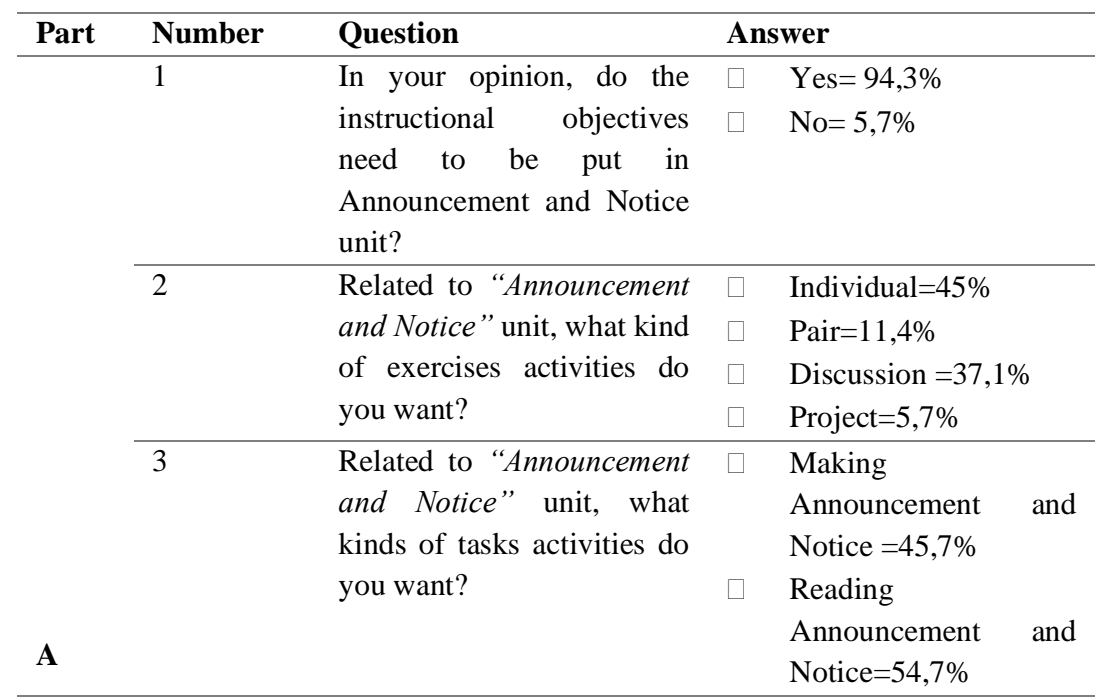




\begin{tabular}{|c|c|c|}
\hline 4 & $\begin{array}{l}\text { Does the summary need to } \\
\text { be put on "Announcement } \\
\text { and Notice" unit? }\end{array}$ & $\begin{array}{l}\text { Yes }=85,7 \% \\
\mathrm{No}=14,3 \%\end{array}$ \\
\hline 5 & $\begin{array}{l}\text { In relation to the learning } \\
\text { "Announcement and } \\
\text { Notice" unit, what kinds of } \\
\text { reflection do you want? }\end{array}$ & $\begin{array}{l}\square \quad \text { Note taking } \\
=77,1 \% \\
\square \text { Presentation }=22,9 \%\end{array}$ \\
\hline 6 & $\begin{array}{l}\text { Does the glossary (words } \\
\text { list) need to be put on } \\
\text { "Announcement and } \\
\text { Notice" unit? }\end{array}$ & $\begin{array}{l}\text { Yes }=71,4 \% \\
\mathrm{No}=28,6 \%\end{array}$ \\
\hline
\end{tabular}

In the part A, the students want instructional objectives to be put in Announcement and Notice unit, they like if given individual activity, they like if asked to read Announcement and Notice, they want summary to be put in Announcement and Notice unit, they like if they are asked to note taking as a reflection and they want glossary to be put in Announcement and Notice unit. Furthermore, part B came into a conclusion as shown in a table below;

Table 3. Result of questionnaire part B

\begin{tabular}{|c|c|c|c|c|}
\hline Part & Number & Question & & wer \\
\hline \multirow{17}{*}{ B } & 7 & If the material & $\square$ & The Importance of \\
\hline & & "Announcement and Notice" & & Having \\
\hline & & based on Islam has been & & Word $=68,6 \%$ \\
\hline & & created, so what topics do & $\square$ & The Celebration of \\
\hline & & you want? & & Mawlid \\
\hline & & & & $\mathrm{Nabi}=28,6 \%$ \\
\hline & & & $\square$ & The Celebration of \\
\hline & & & & Islamic \\
\hline & & & & Year $=2,9 \%$ \\
\hline & 8 & What kind & $\square$ & Annoncement "Tabligh \\
\hline & & "Announcement and Notice" & & Akbar" $=17,1 \%$ \\
\hline & & based on Islam that you have & $\square$ & Annoncement "Festival \\
\hline & & heard or read? & & Anak Saleh"=5,7\% \\
\hline & & & $\square$ & Notice "Kebersihan \\
\hline & & & & merupakan sebagian \\
\hline & & & & dari Iman"=57,1\% \\
\hline & & & $\square$ & $\begin{array}{l}\text { Notice "Jangan ribut, } \\
\text { sedang Sholat!" }=20 \%\end{array}$ \\
\hline
\end{tabular}

This part consisted of two questions; the students want The Importance of Having Good Word as a topic in Announcement and Notice unit and they heard more about Notice "Kebersihan merupakan sebagian dari Iman". Then, also the part C was found a data as shown in the table below: 
Table 4. Result of questionnaire part C

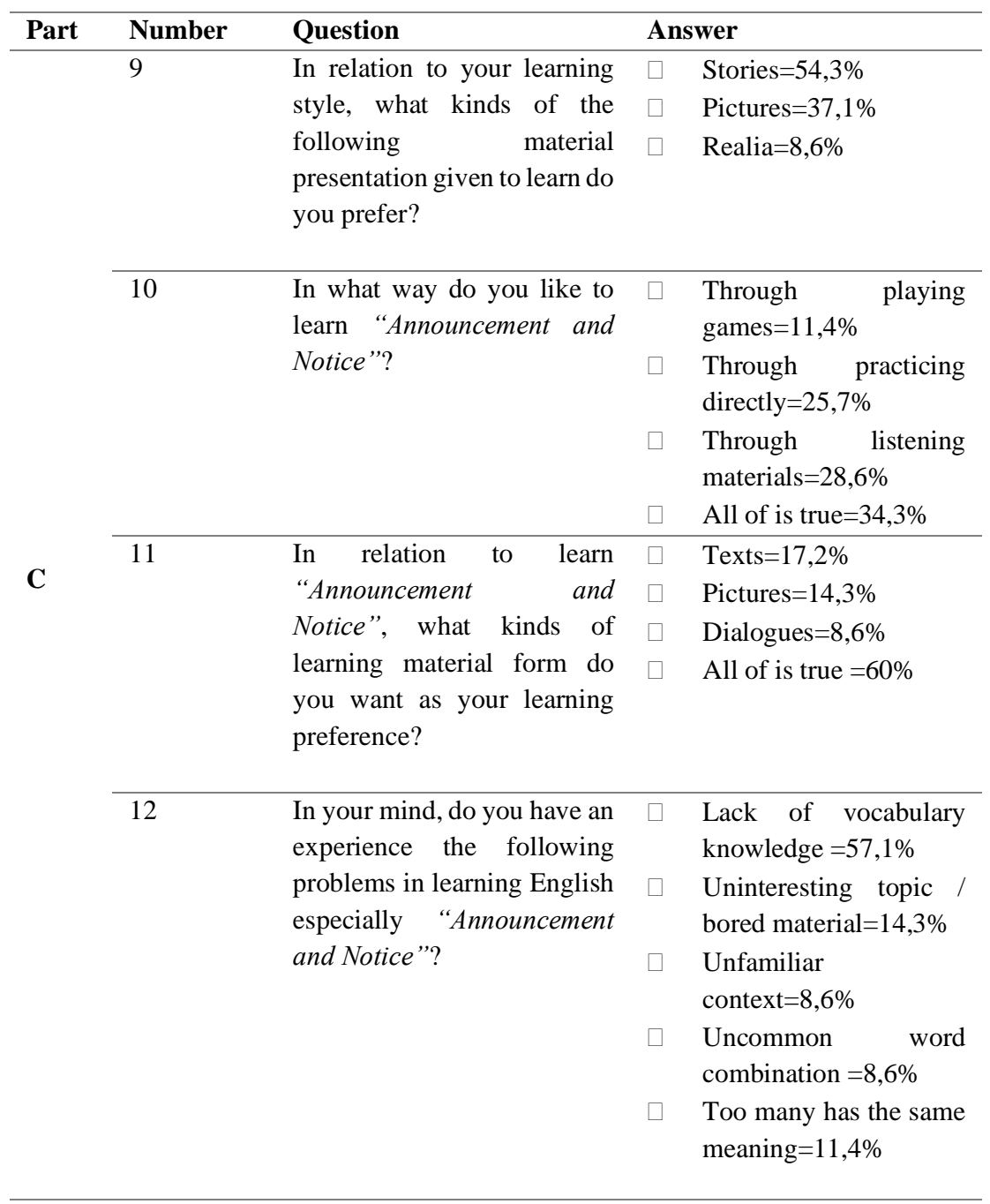

Part $\mathrm{C}$ consisted of 4 questions, as a conclusion found that the students want stories as material presentation in Announcement and Notice unit, they like to learn through practicing directly and through listening materials., they also like to learn by Text and Pictures, and the last the students most problem is lack vocabulary knowledge.

Table 5. The List of Need Inventory

\begin{tabular}{lll}
\hline No & \multicolumn{1}{c}{ Questions } & \multicolumn{1}{c}{ Answers } \\
\hline $\mathbf{1}$ & $\begin{array}{l}\text { In your opinion, do the instructional objectives need to be put in } \\
\text { Announcement and Notice unit? }\end{array}$ & $\begin{array}{l}\text { The students want the instructional } \\
\text { objectives to be put in Announcement } \\
\text { and Notice unit }\end{array}$ \\
\hline $\mathbf{2}$ & $\begin{array}{l}\text { Related to "Announcement and Notice" unit, what kind of exercises } \\
\text { activities do you want? }\end{array}$ & $\begin{array}{l}\text { The students like if they are given an } \\
\text { individual activity }\end{array}$ \\
\hline $\mathbf{3}$ & $\begin{array}{l}\text { Related to "Announcement and Notice" unit, what kinds of tasks } \\
\text { activities do you want? }\end{array}$ & $\begin{array}{l}\text { The students like if they are asked to } \\
\text { read Announcement and Notice }\end{array}$
\end{tabular}




\begin{tabular}{|c|c|c|}
\hline 4 & Does the summary need to be put on "Announcement and Notice" unit? & $\begin{array}{l}\text { The students want summary to be put } \\
\text { in Announcement and Notice unit }\end{array}$ \\
\hline 5 & $\begin{array}{l}\text { In relation to the learning "Announcement and Notice" unit, what kinds } \\
\text { of reflection do you want? }\end{array}$ & $\begin{array}{l}\text { The students like if they are asked to } \\
\text { note taking as a reflection }\end{array}$ \\
\hline 6 & $\begin{array}{l}\text { Does the glossary (words list) need to be put on "Announcement and } \\
\text { Notice" unit? }\end{array}$ & $\begin{array}{l}\text { The students want glossary to be put in } \\
\text { Announcement and Notice unit }\end{array}$ \\
\hline 7 & $\begin{array}{l}\text { If the material "Announcement and Notice" based on Islam has been } \\
\text { created, so what topics do you want? }\end{array}$ & $\begin{array}{l}\text { The students want The Importance of } \\
\text { Having Good Word as a topic in } \\
\text { Announcement and Notice unit }\end{array}$ \\
\hline 8 & $\begin{array}{l}\text { What kind of "Announcement and Notice" based on Islam that you have } \\
\text { heard or read? }\end{array}$ & $\begin{array}{l}\text { The students heard more about Notice } \\
\text { "Kebersihan merupakan sebagian dari } \\
\text { Iman" }\end{array}$ \\
\hline 9 & $\begin{array}{l}\text { In relation to your learning style, what kinds of the following material } \\
\text { presentation given to learn do you prefer? }\end{array}$ & $\begin{array}{l}\text { The students want stories as material } \\
\text { presentation in Announcement and } \\
\text { Notice unit }\end{array}$ \\
\hline 10 & In what way do you like to learn "Announcement and Notice”? & $\begin{array}{l}\text { The students like to learn the material } \\
\text { through playing games, practicing } \\
\text { directly and through listening } \\
\text { materials. }\end{array}$ \\
\hline 11 & $\begin{array}{l}\text { In relation to learn "Announcement and Notice", what kinds of learning } \\
\text { material form do you want as your learning preference? }\end{array}$ & $\begin{array}{l}\text { The students like to learn by Text } \\
\text { Pictures and Dialogues. }\end{array}$ \\
\hline 12 & $\begin{array}{l}\text { In your mind, do you have an experience the following problems in } \\
\text { learning English especially "Announcement and Notice"? }\end{array}$ & $\begin{array}{l}\text { The students most problem is lack } \\
\text { vocabulary knowledge }\end{array}$ \\
\hline
\end{tabular}

\section{The Currently Used English Teaching Material}

The currently used English teaching material was from the textbook "Bahasa Inggris: When English Rings a Bell”. The content of the material on this book especially on the material Announcement and Notice showed that it was still general and had no Islamic value on it.

The capture below showed the material Announcement and Notice form the textbook. 

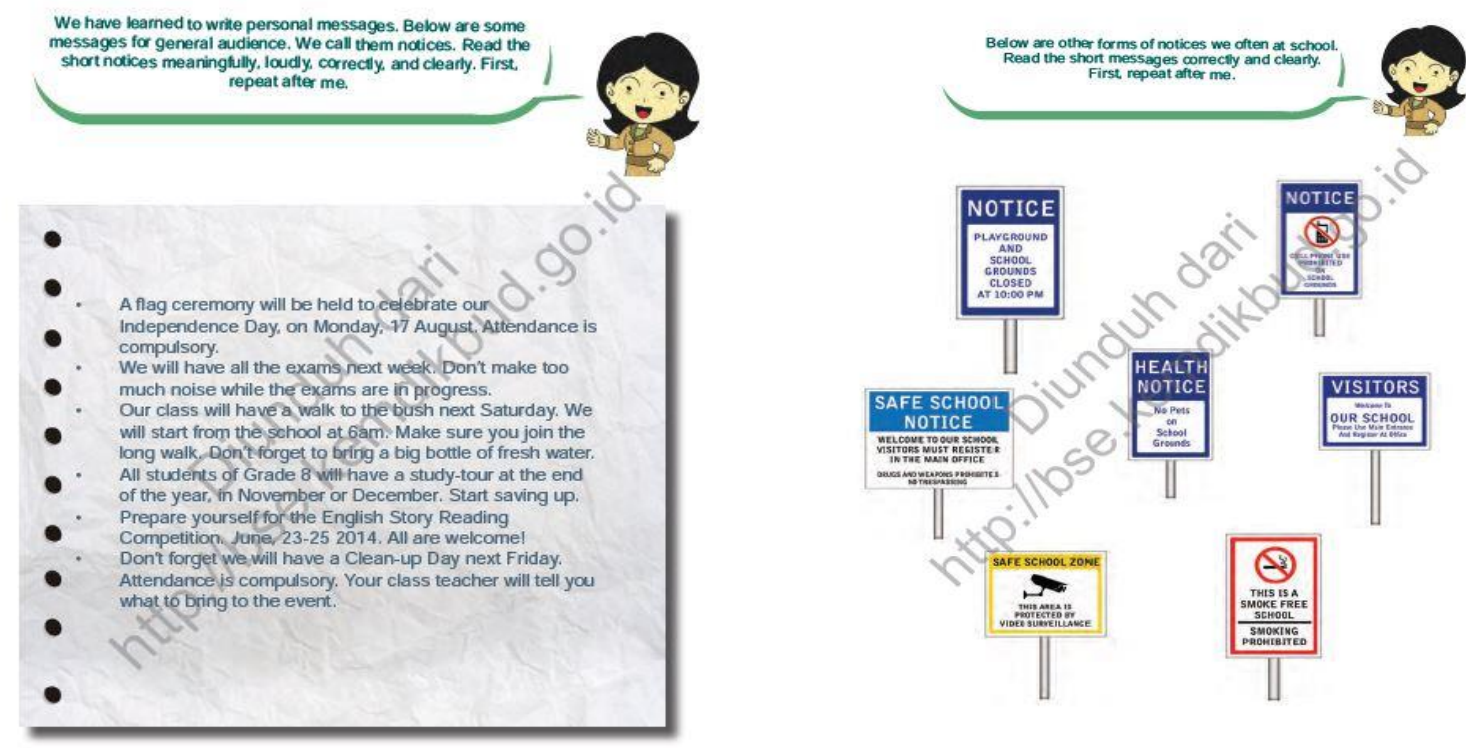

\section{The Design and The Development of Content Materials}

\section{a. The Design of Content Materials}

In this phase, a design of blue print was made. The blue print divided into six components. The components were the topic of each meeting, content of materials, primary skill, the flow of skills, learning activities that is based on scientific approaches that consist of five approaches (observing, questioning, collecting information, associating, and communicating), and the last was learning instructions that consist of five parts (pre study instruction, type of activity, amount of the activity in meeting, text structure and glossary).

The blueprint was used to develop an English learning text book based on Islamic values for students of Junior High School. The components on the blue print explained below:

\section{Content Materials}

The topic was forming the basic competences 3.12 and 4.12 based on SMP/Mts syllabus, it leads 2 meetings from 1 topic (The importance of Having Good Words). The first is talk about explanation of Announcement and the second is talk about explanation of Notice.

2. Primary Skill and the Flow of Skills

Primary skill was the major skill that was taught in a meeting. Therefore, the flow of skills was the skill flows that appeared during the learning process when the material was taught. Generally, there are four skills in English. They are reading, writing, listening, and speaking.

In the first and the second meeting, the learning process is started and finished with reading as the primary skill and the middle of the process there are writing and speaking skills that related with Announcement and Notice.

3. Learning Activities 
The learning activities were using scientific approach that consists of five elements based on 2013 Curriculum. They are observing, questioning, collecting information, associating, and communicating. These elements are used to make the materials systematic. The activities all meetings were observing, questioning, exploring, associating, and communicating.

4. Learning Instruction

Learning instruction consisted of four parts. They were pre-study, type of activity, amount of activity, text structure, and glossary. Pre-study was something that teacher provided to motivate the students and to make them ready for studying. Type of activity is the type of the assignment or task given. It can be self-activity, pair activity, group, etc. From the first until the second meeting, the project is only individual work.

Moreover, amount activity is the total of the activity that given in each meeting. The first meeting consisted of 6 activities, and the second meeting had 5 activities. The next was text structure. It was the type or kind of structure or grammatical rules that used in that material like the tenses. As just stated before, the development included two developed units. The first was about Announcement material, the text structure was explained about Simple Future Tense, then the second was about Notice material, the text structure was presented the imperative sentence.

The last learning instruction was glossary. Glossary was put in the end of the chapter. Additionally, the learning instructions stated before were designed based on the result of need analysis especially in the text structure and activity. Therefore, the students' need analysis was also been a resource to design the product especially in type of activity and the appearance of the product.

\section{b. The Development of the Content Material}

In this phase, the development material was made based on the blue print that consisted of six components (the topic of each meeting, content of materials, primary skill, the flow of skills, scientific approaches and learning instructions). The development was covering basic competences 3.12 and 4.12 based the syllabus of 2013 Curriculum.

\section{The Result of Expert's Validation Towards the Materials' Contents}

\section{a. The Result of Development of Rubric for Expert}

This section showed some aspects on Announcement and Notice material. They included the aspect of material and the aspect of learning. Those aspects were discussed on the following.

1) The Aspect of Materials 
The aspect of materials included Coverage (breadth and depth) of material content, Clarity of content, Organizational structure/order of content, Clarity of examples included, Adequacy of examples included, Clarity of the language used, Suitability of language with target users, Clarity of the information on the illustration image, Suitability of the assignment/task with the material, Balance the proportion of practice questions/tests with the material and the last Series of questions presented.

\section{2) The Aspect of Learning}

The aspect of learning covered some aspects those were Suitability of basic competences with the material, Clarity of sub-unit titles, Clarity of learning instructions, Variations in the delivery of types of information, Accuracy in explaining conceptual material, Accuracy in explanation of practical material, Attractiveness of the material in motivating students, Clarity of Task instructions, Clarity of question / test and Difficulty level of questions / tests.

3) The Aspect of Graphics Feasibility

This aspect consisted of four aspects, those are cover of the chapter, variations in the use of images, combined use of fonts and clarity of the colors used. The result of the validation checklist forms the first and the second expert are reviewed below:

Table 6. Result of Validation Checklist

\begin{tabular}{|c|c|c|}
\hline Item & Score (Expert 1\&2) & Description \\
\hline \multicolumn{3}{|c|}{ The Aspect of Materials } \\
\hline 1 & 3,5 & Appropriate \\
\hline 2 & 4 & Appropriate \\
\hline 3 & 4 & Appropriate \\
\hline 4 & 4 & Appropriate \\
\hline 5 & 4 & Appropriate \\
\hline 6 & 4 & Appropriate \\
\hline 7 & 3,5 & Appropriate \\
\hline 8 & 3,5 & Appropriate \\
\hline 9 & 4 & Appropriate \\
\hline 10 & 4 & Appropriate \\
\hline 11 & 3,5 & Appropriate \\
\hline \multicolumn{3}{|c|}{ The Aspect of Learning } \\
\hline $\mathbf{1}$ & 3,5 & Appropriate \\
\hline 2 & 4 & Appropriate \\
\hline 3 & 4 & Appropriate \\
\hline 4 & 3,5 & Appropriate \\
\hline 5 & 3,5 & Appropriate \\
\hline 6 & 3,5 & Appropriate \\
\hline 7 & 3,5 & Appropriate \\
\hline
\end{tabular}




\begin{tabular}{ccc}
\hline $\mathbf{8}$ & 3,5 & Appropriate \\
\hline $\mathbf{9}$ & 3,5 & Appropriate \\
\hline \multicolumn{3}{|c}{ The Aspect of Graphics Feasibility } \\
\hline $\mathbf{1}$ & 4 & Appropriate \\
\hline $\mathbf{3}$ & 4 & Appropriate \\
\hline $\mathbf{4}$ & 4 & Appropriate \\
\hline
\end{tabular}

\section{b. The Result of Development and Expert Judgment Suggestion}

Based on the development materials, the expert found that the material was good enough, precise and clear to be used as a reference for teaching English. However, the experts asked to put the basic competencies on the material clearly, changed the color of the font to be more readable, rid an unimportant image and mended some grammatical errors.

\section{Discussion}

This research was integrated Islamic Values in Announcement and Notice unit, it is based on Curriculum 2013. This curriculum is based on the scientific approach. This scientific approach can help students in learning process, as stated by Machine (2014) that implementing scientific approach in the learning process can have a positive effect in cognitive, affective and psychomotor as well as learning outcomes and has achieved the specified classical completeness. The scientific approach used is the scientific approach in which there are activities, namely observing, questioning, exploring, associating and communicating (Kemendikbud: 2013). On the development material, the experts and the teacher validated the material using the validation checklist. The final result of the development of the material contains the material of Announcement and Notice that is integrated with Islamic values, so that students will get both during the learning process. In line with Umam (2014) that by incorporating Islamic values in English teaching, the santri can maintain their Islamic identity and are not easily contaminated by Western values and, at the same time, they will have English competence as a means to face their future.

\section{CONCLUSION}

Based on findings and discussion that have been presented previously, it can be concluded that students had varied needs for English material especially for the material Announcement and Notice from the organization of the material, the content of the material and learners' characteristics. Then, the English material that currently used in the school was too general and still far from the term integrated with Islamic values. After that, the English material was 
developed based on the blue print and the questionnaire that had been spread for students. Therefore, "The Importance of Having Good Word" was chosen as the topic for Announcement and Notice unit based on the questionnaire. And the last, the product of English material had been made and validated by the experts using validation checklist, the result of the validation checklist showed that the material could be used as another reference in teaching the material of Announcement and Notice in Junior High School, especially Islamic Junior High School.

\section{REFERENCE}

Annisa, A., \& Hadijah, S. (2017). The integration of Islamic values in English teaching and learning process at MAN Model Palangka Raya. In Proceedings of International Conference on English Language Teaching (INACELT) (Vol. 1, No. 1, pp. 35-50).

Anggraeni, Raden Roro Widya Puspita. (2012). Pengembangan Multimedia Pembelajaran Mata Kuliah Pengembangan E-Learning Berbasis Web pada Prodi S1 Teknologi Pendidikan Universitas Negeri Yogyakarta. Yogyakarta: Lumbung Pustaka Universitas Negeri Yogyakarta.

Amri, Ulil Syafri. (2014). Pendidikan Karakter Berbasis Al-Qur'an. Jakarta: Rajawali Pers.

Chaeruman. (2009). Mengembangkan Sistem Pembelajaran dengan Model ADDIE. Jakarta: PT Remaja Rosdakarya.

Darwis, Jamaluddin. (2008). English for Islamic Studies. Jakarta: PT Rajagrafindo Persada.

Jalaluddin, H. (2016). Pendidikan Islam Pendekatan Sistem dan Proses. Jakarta: PT. Rajagrafindo Persada.

Kemendikbud. (2013). Panduan Penilaian Pada SMK. Retrieved from http://akhmadsudrajat.files.wordpress.com /2015/12panduanpenilaian-smk.pdf.

Nurpahmi, S. English for Specific Purposes: An Integrated Approach. Jurnal lentera Pendidikan. 2017.

Machin, A. (2014). Implementasi Pendekatan Saintifik, Penanaman Karakter dan Konservasi pada Pembelajaran Materi Pertumbuhan. Jurnal Pendidikan IPA Indonesia, 3(1).

Richards, J. (2001). Curriculum Development in Lnguage Education. Cambridge: Cambridge University Press.

Umam, C. (2014). Maintaining Islamic Values in English Language Teaching in Indonesian Pesantrens. DIDAKTIKA Religia: Journal of Islamic education, 2(1), 227-242.

Yassi, Hakim \& Kaharuddin. (2018). Syllabus Design for English Language Teaching Second Edition. Jakarta: Trust Media Publishing.

Yaumi, Muhammad. (2016). Prinsisp-Prinsip Desain Pembelajaran. Jakarata: Kencana. 